\title{
SOME NEW MOLLUSCAN HOSTS OF DICROCOELIUM DENDRITICUM IN SPAIN
}

\author{
J.-M. ALUNDA and F.-A. ROJO-VAZQUEZ*
}

SUMMARY. Twenty species of the family Helicidae (Gastropoda, Pulmonata) from the N.W. of Spain were tested as hosts for $D$. dendriticum in experimental conditions. The relationship between the egg hatching in the digestive tract and the development of sporocysts (108-110 days after egg ingestion) was studied. Three species were found to be new intermediate hosts of this trematode : Candidula intersecta, Helicella corderoi and $H$. jamuzensis.

On the basis of the results obtained, the ecological value of the positive species in the life cycle of the parasite is discussed.

\section{Nouveaux mollusques hôtes intermédiaires de Dicrocoelium dendriticum en Espagne.}

RÉSUMÉ. Vingt espèces de la famille Helicidae (Gastropoda, Pulmonata) du nord-ouest de l'Espagne ont été testées comme hôtes de $D$. dendriticum dans des conditions expérimentales. Le rapport entre l'éclosion des œufs dans le tube digestif et le développement des sporocystes (108110 jours après l'ingestion des œufs) a été étudié. On a trouvé que 3 espèces étaient des nouveaux hôtes intermédiaires de ce Trématode : Candidula intersecta, Helicella corderoi et $H$. jamuzensis.

\section{Introduction}

It is not necessary to underline the economic importance of infections caused by $D$. dendriticum, already described by some authors (Euzeby, 1971) nor the role played in its ecology by molluscs belonging to the Familia Helicidae (Gastropoda, Pulmonata).

However, knowledge of the relationship established between the trematode and its molluscan intermediate hosts - of extreme importance in the understanding of epizootiology of discrocoeliosis and the establishment of control measures - in many European countries is far from complete. In Spain, in spite of the experimental work carried out (Río Lozano, 1967) the situation leaves much to be desired. In neighbouring countries, there is either a lack of studies or the work that has been done has led to questionable results (Badie et al., 1973).

Taking this situation into account, the present paper describes the results obtained from studies on the experimental infection of 20 species of Helicidae collected

\footnotetext{
* Dpto. Parasitología, Fac. Farmacia, Univ. Salamanca, Spain.
}

Accepté le 2 mai 1983 . 
from the N.W. of Spain. The work also attempts to study their ecological value and to discuss some of the aspects related to the specificity of $D$. dendriticum, which up to the present has not been studied in sufficient depth (Timon-David, 1965 ; Boray, 1970).

\section{Material and methods}

Infections were carried out according to Alunda and Rojo-Vazquez (1982) using filter paper as the vehicle for the parasite eggs. These were obtained from naturally infected sheep belonging to a close-type flock grazing in Villacete (León, NW Spain). Snails collected from different sites the NW of Spain were held in the laboratory for 40 days to discover the presence of natural infections not noticed in the previous sampling. The nomenclature of the species was after Manga-Gonzalez (1976) and the notes of Gittenberger (1980). In order to show that hatching was invariable, analyses were carried out in our laboratory at intervals (up to 40 days) on Monacha (Ashfordia) gramulata and the process was seen to remain unaltered.

Throughout the paper, use will be made of the term compatibility to refer to the positive relationship between host and parasite.

108-110 days after egg ingestion, molluscs were taken from the Petri dishes (of different sizes according to the size of the snail species) where they had been infected, then sacrified by immersion in tap water and observed at $40 \mathrm{X}$ under a stereomicroscope.

\section{Results}

Great variation was observed and the hatching percentage ranged from almost negligible (Hygromia cantabrica covadongae) to values greater than $80 \%$, as shown in Table I. There were clear differences on comparing the mean values of the subfamilies represented.

As shown in Table $I$, it was possible to find appreciable parasite development in only four of the species. The relationship between the presence of larval stages $(+$ or -$)$ and the hatching values is shown in figure 1. Developed sporocysts were absent in snail species with hatching percentages lower than $50 \%$, though higher values did not guarantee infection (Cochlicella barbara, Euparypha pisana, etc.). The only species of the genus Helicella Férussac, 1821, which was incompatible with D. dendriticum had the lowest hatching rate (H. cf. madritensis).

\section{Discussion}

Hatching :

Even though some authors agree on the apparent lack of specificity in hatching of $D$. dendriticum eggs (Boray, 1970 ; Alunda and Manga-Gonzalez, 1982), we have found a wide variation in these values in studying a large group of molluscs. This 


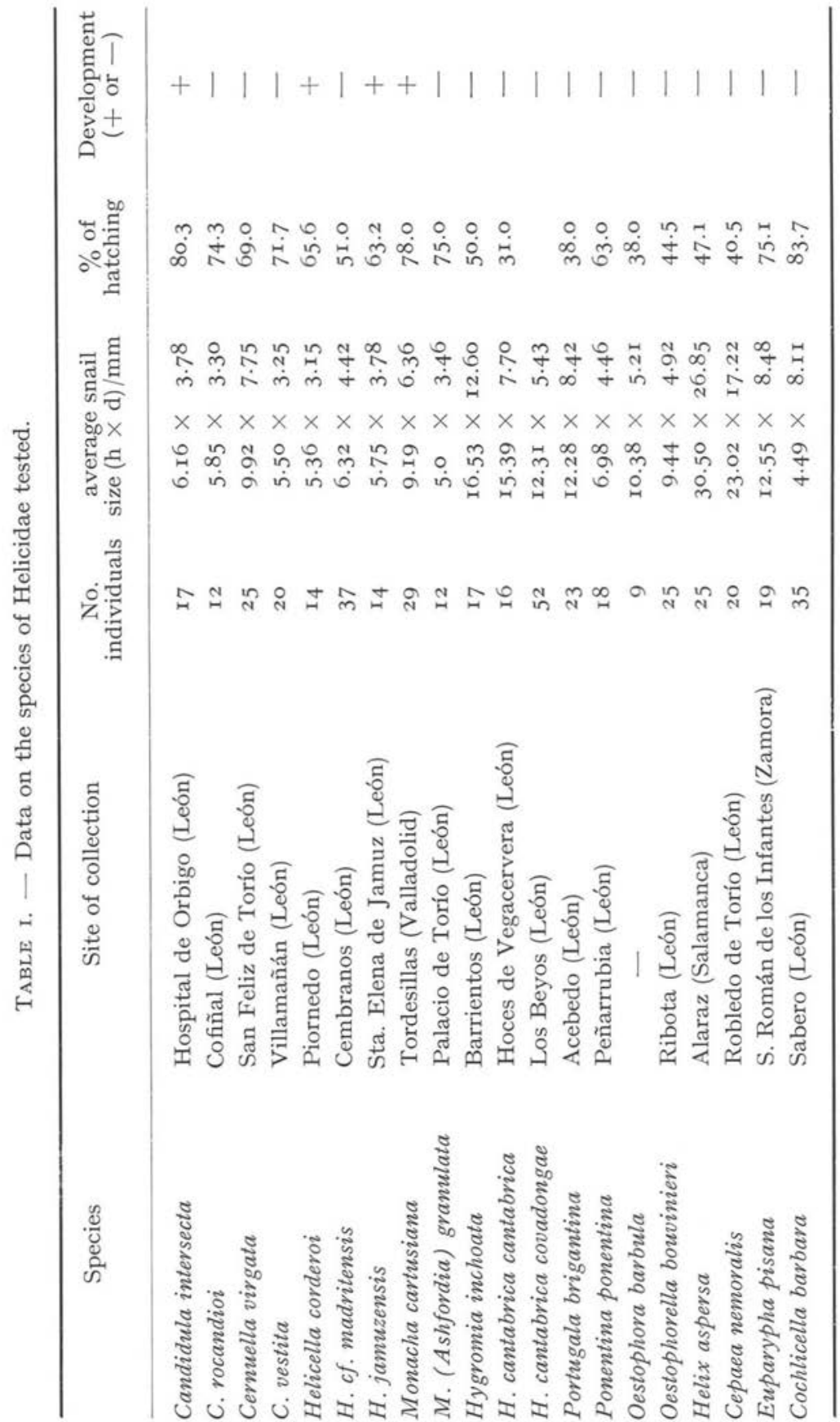




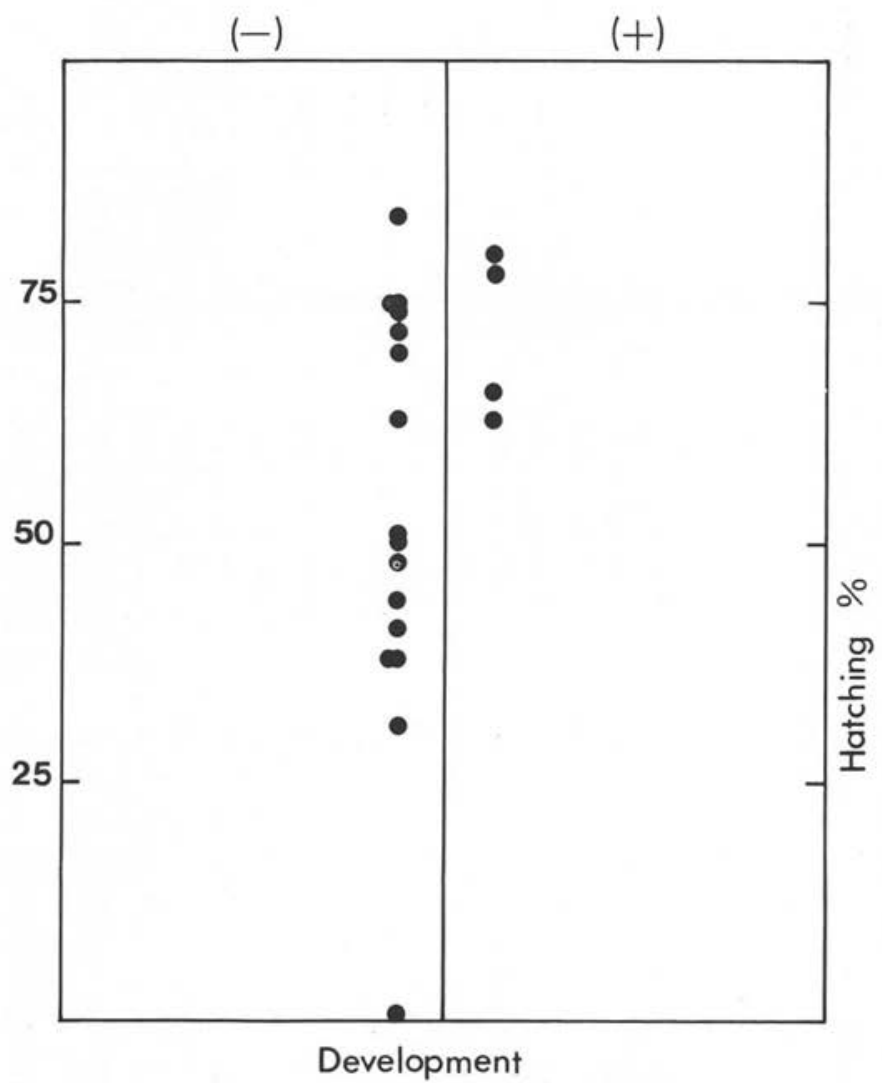

FIG. I. - Relationship between \% of egg hatching in mollusc faeces and the appreciable parasite development (positive or negative).

variation could indicate a certain degree of specificity. The slight specificity shown regarding hatching seems to be an ecological characteristic. This is not surprising if we consider that the digestive tract is really a modified part of the environment. In this way is easy to interpret the variations shown in some subfamilies, by the different species, in relation to the habitats in which they normally live - Helix aspersa $(47.1 \%)$ and Euparypha pisana $(75.1 \%)-$. However, these results should be interpreted with caution, since the occurence of two species in the same area does not necessarily imply similar feeding habits; consequently the physicochemical conditions of the digestive tract, the final cause in the hatching of $D$. dendriticum miracidia (Ratcliffe, 1968 ; Mitterer, 1975), may also differ.

The digestive tract of terrestrial snails acts as an ecological filter ; a rather inneficient one, however, since high hatching levels do not guarantee later parasite development. 
Development :

Independently of the cases without parasite development it is not possible to compare the compatibility of host-parasite relationship on the basis of the percentage of infected snails, since such percentages do not constitute a specific invariance but rather a populational one in this system (Alunda and Rojo-Vazquez, 1982). Furthermore, parasite " development " (size of the sporocysts) is principally the result of the interaction between the size (age) of the molluscs and the infective dose (Alunda and Rojo-Vazquez, in press). Thus, and taking into account the method of infection (ad libitum feeding on contaminated material), the only way of classifying the systems was the positivity or negativity of parasite development, when molluscs were sacrified.

The extremely low specificity and its non-phylogenetic nature, as far as we know excludes all hypotheses, though it would be of interest to discuss some aspects.

None of the species of Cermuella Schlüter, 1838 tested proved to be a suitable host. Our results differ from those of Kalkan (1971) who described Cernuella virgata as a suitable host for $D$. dendriticum on the basis of natural infections. Nevertheless, in spite of being a widely distributed species in some European countries, it has never been described as an intermediate host of this trematode.

The case of Cepaea nemoralis seems to be almost identical ; it has been frequently reported by certain Russian authors (Korzh et al., 1975; Kuzovkin et al., 1975) as intermediate host of $D$. dendriticum on the basis of natural infections. However, this has never been reported in Central Europe, where the species is very abundant and neither have we been able to infect snails in experimental conditions.

It is possible that in both cases one is dealing with compatible and incompatible populations - common in mollusc-trematode systems - and not with errors in the adscription of larval stages to adult trematodes.

In general, the results obtained regarding parasite development are comprehensible on the basis of the ecology of molluscs assayed. Accordingly the participation of Monacha cartusiana and the incompatibility of M. (Ashfordia) granulata.

As a corollary, the following species may be said to constitute new intermediate hosts records for D. dendriticum : Candidula intersecta, Helicella corderoi and H. jamuzensis. Moreover, we believe that some species assayed, with positive results could be responsible for the transmission of this parasite in other European and North African countries.

\section{REFERENCES}

Alunda J. M., Manga-GonzÁlez M. Y. : Susceptibility of some species of the genus Helicella Férussac, 1821 (Gastropoda, Helicidae) to the infection by Dicrocoelium dendriticum (Trematoda), Malacologia, 1982, 22, 51-54.

Alunda J. M., Rojo-VÁzouez F. A. : Susceptibility of some populations of Cernuella (Xeromagna) cespitum arigonis (Schmidt, 1875) (Gastropoda, Helicidae) from the Douro Basin (Iberian Peninsula) to the infection by Dicrocoelium dendriticum (Trematoda), Malacologia, 1982, 22,

Alund-43. J. M., Rojo-VÁzQUEz F. A. : Effect of infection rate and host age on the intramolluscan development of Dicrocoelium dendriticum, Helminthologia (in press). 
Badie A., Vincent M., Morel-Vareille C., Rondelaud D. : Cycle de Dicrocoelium dendriticum (Rudolphi, I819) en Limousin. Éthologie des fourmis parasitées par les métacercaires. C.R. Sci. Soc. Biologie, 1973, 167, 725-727.

Boray J. C. : Studien über die Biologie des Lanzettegels, Dicrocoelium dendriticum, Zeits. Parasitenkunde, 1970, 34, 25-26.

EuzeBy J. : Les maladies vermineuses des animaux domestiques et leurs incidences sur la pathologie humaine. Tome II, Maladies dues aux Plathelminthes, Vigot Frères, Paris, I97I.

Gittenberger E. : Three notes on iberian terrestrial gastropods, Zool. Mededelingen, 1980, 5s, 2OI-2O3.

Kalkan A. : Dicrocoelium dendriticum (Rudolphi, r8I9) Looss, r899 in Turkey. I. Field studies on the intermediate and final hosts in the South Marmara region, 1968, Br. Vet. J., I971, $127,67-75$.

Korzh K. P., Kuzovkin E. M., Evtushenko Yu. M., Vysochanskit B. D., Sheveleva O. N., Merzhanov I. V., Sopilnik G. M. : (Assessment of pastures for Dicrocoelium lanceolatum infection and its control in the Ukrainian Carpathian Mountains), Problemy Parazitologii. Materialy VIII nauchnoi konferentsii parazitologov UkSSR, 1975, $1,247-249$. (In Russian.)

Kuzovkin E. M., Korzh K. P., Sheveleva O. N., Kolomatskaya L. P. : (Terrestrial molluscs infected with Dicrocoelium in the pastures of Chernovitsa region and their role in the epizootiology of dicrocoeliosis), Problemy Parazitologii. Materialy VIII nauchnoi konferentsii parazitologov UkSSR, 1975, $1,286-287$. (In Russian.)

Manga-GonzÁlez M. Y. : Los Helicidae (Gastropoda, Pulmonata) de la provincia de León, Tesis doct. Fac. Biol. León, 1976, León.

Mrtrerer K. E. : Untersuchungen zum Schlüpfen der Miracidien des kleinen Leberegels Dicrocoelium dendriticum, Zeits. Parasitenkunde, 1975, 48, 35-45.

Ratcliffe L. H. : Hatching of Dicrocoelium lanceolatum eggs, Exp. Parasitol., 1968, 23, 67-78.

Río Lozano J. DEL : Epizootiología de la dicrocoeliosis en la provincia de León, Trabajos Est. Agric. Exp. León (C.S.I.C.), 1967, 4, 163-237.

Timon-David J. : Infestation expérimentale d'une hélicelle par huit espèces de trématodes digénétiques appartenant à quatre familles différentes, Ann. Parasitol. Hum. Comp., I965, 40, I 49-1 54 . 